\title{
The balance of public finances and the health crisis in France
}

\author{
Równoważenie finansów publicznych \\ a kryzys zdrowotny we Francji
}

\begin{abstract}
The balance of public finances has been a cardinal point of financial doctrines since the French Revolution, until today. Sometimes it was conceived as a budgetary balance, of the liberal type, sometimes as an economic and financial balance, of the Keynesian type. Since the beginning of the 2000s, the French state has been looking for "a third way": The state is now conceived as an actor having to seek to manage itself like a business; This objective will find a translation in the "organic law relating to the finance laws" of 1 August 2001. This text introduces into the legal system a certain form of public finance balance, neither completely liberal nor entirely interventionist. But in the current context, faced with a health crisis of an exceptional magnitude and a violent and lasting economic and social crisis, the objective of balance seems exceeded, the State is not a private person nor a public person like others. It has no obligation to balance its budget and the main thing for it is to inspire confidence in the financial markets in order to borrow at the best rate. Given the current health and economic situation, it is essential for the state to continue to borrow in order to protect its popu-
\end{abstract}


lation and jobs in the country. Finally, the question that will arise at the end of the crisis is undoubtedly not that of balancing the budget, but rather that of knowing whether this is not the moment to initiate structural reforms, including our legal system and economic needs for several decades.

Keywords: public finances; health crisis; budget balance; economic and financial balance.

Streszczenie. Od rewolucji francuskiej aż po dzień dzisiejszy równoważenie finansów publicznych jest głównym punktem analiz czynionych przez przedstawicieli doktryn finansowych. Czasem idee te rozumiano jako konieczność zapewniania równowagi budżetowej typu liberalnego, a czasami postrzegano je jako równowagę gospodarczą i finansową typu keynesowskiego. Od początku XX wieku Francja szuka „trzeciej drogi”: państwo jest teraz postrzegane jako podmiot, który musi starać się zarządzać sobą tak, jak czyni się to w biznesie. Takie podejście widać w ustawie organicznej o finansach z 1 sierpnia 2001 r., która ustanawia pewną formę równowagi finansów publicznych, która nie jest w pełni liberalna, ale też nie jest całkowicie interwencjonistyczna. Jednak w obecnym kontekście, w obliczu kryzysu zdrowotnego o wyjątkowej skali oraz gwałtownego i trwałego kryzysu gospodarczego i społecznego, zapewnianie równowagi wydaje się wykraczać poza to, co konieczne - państwo nie jest bowiem ani osobą prywatną, ani publiczną podobną do innych osób. Nie ma więc obowiązku równoważenia swojego budżetu, a najważniejsze dla niego jest wzbudzenie zaufania na rynkach finansowych, aby móc zaciągać jak najkorzystniejsze pożyczki. Biorąc pod uwagę obecną sytuację zdrowotną i gospodarczą, konieczne jest dalsze zadłużanie się państw, by w ten sposób chronić ludność i miejsca pracy w kraju. Po zakończeniu kryzysu istotniejsze będzie zaś podjęcie analizy, czy jest to właściwy moment na rozpoczęcie reform strukturalnych, w tym reformy systemu prawnego i potrzeb gospodarczych na kilka dziesięcioleci, niż bilansowanie budżetu państwa.

Słowa kluczowe: finanse publiczne; kryzys zdrowotny; równowaga budżetowa; bilans ekonomiczny i finansowy. 


\section{The balance of public finances, cardinal point of financial doctrines}

The balance of public finances tends to become more and more wishful thinking. The current health context and its consequences for France's debt are indeed moving it away from this objective. However, the balance of public finances is clearly a pillar of financial doctrines. All economic schools of thought have taken an interest in it; each with a different interpretation.

The Physiocrats, at the time of the French Revolution, advocated for an absence of a debt and a deficit and, therefore, a respect for a so-called budgetary balance, that is to say that a revenue should equal an expenditure. For this current liberal thought, forged by François Quesnay, AnneRobert-Jacques Turgot or even by Pierre-Samuel Dupont de Nemours, the tax model of the Ancien Régime was not fair and required to design a new system of economics which would considerably influence the revolutionaries. According to the new idea, the "gendarme state" must be withdrawn from economic activities and not to assume the tasks inherently incumbent on private economic actors. These rules did not translate into legal effects at the time ${ }^{1}$. No principle of balance has been enshrined in the legal order. Moreover, the French state was in debt from the end of the 18th century. In volume 1 of his Dictionary of Finances, Léon Say showed that the debt did not stop increasing until the end of the 19th century. Thus, for example, it amounted in 1793 to $127,803,000$ francs, in 1830 to 202,381,180 francs, and in 1888 to more than 30 billion francs. Balanced public finances, understood as a balanced budget, thus, have constituted an illusion, a utopia, a laudable objective ${ }^{2}$ that is difficult to achieve in law and in practice ${ }^{3}$.

Balancing public finances became even more difficult to achieve after the crisis of 1929 and the two World Wars. Faced with the inability of

1 Cf. E. Allix, Traité élémentaire de science des finances et de législation financière française, Paris, Rousseau \& cie, 6e éd., 1931, p. 6.

2 Ch. d'Audiffret, Le système financier de la France, Vol. 2, 1863, p. 8.

3 L. Tallineau, Chapitre introductif, "L’équilibre budgétaire”, Économica, 1994, p. XV. 
the "state gendarme" to provide responses to a deregulated economic market and the necessary reconstruction of the country, the intervention of the state and infra-state communities appeared necessary if not essential. This interventionism was desired and encouraged by the budgetary doctrine. For the British economist, John Maynard Keynes, it has become necessary to institute an economic equilibrium radically different from that proposed by the classical liberals. He showed that an insufficient demand risks creating high unemployment. The demand must, therefore, be stimulated by the private sector, but also by the public community. Not condemning the budgetary imbalance, he advocated the implementation of an anti-cyclical policy. The budget may be in deficit when demand needs to be revived (because the state will increase its own spending). Conversely, if production is lower than a demand, than the state will be able to vote a surplus budget (it will, therefore, limit its own demand); the ultimate objective of such an approach being to achieve full employment. This conception of the balance of public finances and the role of the state has been implemented in France. As early as in 1956, the decree of 19 June determining the mode of a presentation of the state budget recognized the economic function of the state budget. More precisely, "the time is long past when the revenues collected by the state to cover the operating expenses of public services which were almost exclusively sovereign had no impact on the national economy. By increasing its interventions, the state is present in all branches of activity in the country. The means at its disposal, like the resources it extracts, now have a profound influence on the life of the nation, its economic orientation, its social future". The ordinance of 2 January 1959 goes in the same direction by stating that the finance laws determine the amount of a revenue and an expenditure taking into account an economic and financial balance, which they also determine. Under an effect of a reconstruction of the country, the economic and financial balance appears as a determining and saving principle. In a few years, we have thus gone from an illusion of the principle of a budgetary balance to the reality of an economic and financial balance, the only way 
to effectively support and ensure the resilience of the national community faced with economic crises and unprecedented social policies until now ${ }^{4}$.

The 1970s, marked by the oil shocks, suddenly led the political authorities to accept a doctrine of abandoning the above-described concept of equilibrium, which had not made it possible to stem the harmful effects of an economic crisis that gave rise to mass unemployment. France left the glorious Thirty Years ${ }^{5}$, which were a period of full employment, to enter several decades of high unemployment. The state initially considered this to be a cyclical crisis that could be resolved by Keynesian solutions, so by promoting a demand. But such an idea did not work. Politicians and scholars were, therefore, once again committed to upholding the fundamental principles of liberalism and balanced budgets.

The idea therefore emerged that it was necessary to give up the demand policy and replace it with another type of an economic policy favoring production - a supply policy. This entails replacing policies that aim to support demand with policies that aim to support production and business.

The "welfare state" model was, therefore, no longer effective and another had to be proposed, without asserting that the state must imperatively devote itself to a liberal doctrine. The state is now conceived as an actor seeking to manage itself like a business does - an objective to be implemented in the "organic law relating to the finance laws" of 1 August 2001. This text has introduced into the legal system various notions of balance in the preparation and execution of the State budget and more generally of the public administration. A certain form of public finance balance, neither entirely liberal nor entirely interventionist, has thus legally materialized. But, in the current context, faced with a health crisis of an exceptional magnitude and a violent and lasting economic and social crisis, one can wonder if this objective, straddling liberal and interventionist doctrines, should not be set aside.

4 M.-A. Chaigneau, Le dogme de l'équilibre financier: plaidoyer pour des finances publiques saines et une fiscalité juste, SPM, 2019.

5 Expression that we owe to Jean Fourastié, Les Trente Glorieuses, ou la révolution invisible, Fayard, 1979. 


\section{The balance of public finances, a concrete objective}

At the time of the adoption of the "organic law" of 1 August 2001 relating to finance laws, the choice was made to state that "the finance laws determine, for a financial year, the nature, amount and allocation of State resources and charges, as well as the resulting budgetary and financial balance. They take into account a defined economic balance, as well as the objectives and results of the programs they determine" ${ }^{\text {. }}$. By itself, this article of the "organic law" of 1 August 2001 perfectly sums up the ambivalence of the legislature. It mentions the "budgetary balance" (which is said to be liberal), but also "financial balance" (which could be already found in the ordinance of 2 January 1959, of Keynesian inspiration). Reading this provision makes it difficult if not impossible to state what is the legislature's preferred conception of the balance of public finances, except that a mixture is made between a classic liberal and interventionist concept of economy and public finances ${ }^{7}$.

This confusion is all the greater since several articles of the "organic law" refer to budgetary balance, while the others suggest that the State must ensure respect for financial balance ${ }^{8}$.

The "organic law" of 1 August 2001 mentions a balanced budget on numerous occasions ${ }^{9}$. This is the case for advance decrees which cannot be issued if they affect the budgetary balance defined by the finance law (Article 13) or for the cancellations of appropriations which aim, to the contrary, to prevent a deterioration of the budget (Article 14). Added to this is the fact that the first part of the finance law must in particular contain the provisions relating to State resources, which affect the budget balance and establish general data on the budget balance, presented in

$6 \quad$ Article $1^{\text {er }}$ de la loi organique No 2001-692 du $1^{\text {er }}$ août 2001 relative aux lois de finances, JORF n 177, 2 août 2001.

7 M. Lascombe, Les vicissitudes de la règle d'or budgétaire [in:] Mélanges en l'honneur du Professeur Joël Molinier, Paris 2012.

8 A. Pariente, Équilibre des finances publiques et programmation pluriannuelle, "Revue Française de Finances Publiques” 2012, No 117, pp. 87-98.

9 For more development see J.-L. Albert, Finances publiques, $11^{\text {ème }}$ éd., Dalloz, 2019;

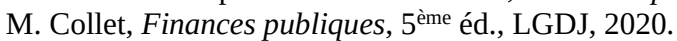


a table of balance (Article 34). The second part of the finance law may for its part include provisions relating to the base, rate and methods of collection of taxes of any kind that do not affect the budget balance (Article 34).

Conversely, the "organic law" of 1 August 2001 refers to a financial balance. It indicates that, when laws and regulations are likely to affect State resources or charges during the year, the consequences of each of them on the components of the financial balance must be assessed and authorized in the next finance law relating to this year (Article 33). We also observe that the first part of the finance law includes the authorizations relating to the loans and the State treasury and it evaluates the resources and the treasury charges which contribute to the achievement of financial balance, presented in a table of funding (Article 34). Finally, the regulation law sets the final amount of cash resources and charges that contributed to achieving financial balance for the corresponding year, presented in a financing table (Article 37).

The financial equilibrium, therefore, seems to concern mainly operations relating to loans. The state is not bound by an obligation of a result. There is in fact no sanction provided for in the event of a failure to respect the balance which is laid down in the initial budget law.

This ambivalence has been reinforced since the entry into force of the revision of 23 July 2008 and the new Article 34 of the Constitution which now provides that "the multiannual orientations of public finances are defined by programming laws. They are part of the objective of balancing the accounts of general government". This is an objective and not a principle of balance, otherwise unqualified.

This shift towards a third way, between classical liberalism and interventionist, is also found in European Union law. The "golden rule" laid down in the treaty on stability, coordination and governance within the Economic and Monetary Union adopted in 2012 and transposed in France by the "organic law" of 17 December 2012 perfectly illustrates such a political and legal phenomenon. By signing this treaty, the Member States of the European Union undertake to have their budgets in a balance or in a surplus. More specifically, the structural deficit should not exceed $0.5 \%$ of GDP for countries whose public debt exceeds $60 \%$ of GDP. For 
others, the clearance is 1\%. In France, the "organic law" of 17 December 2012 provides that the public finance programming laws specify the medium-term objective in the form of a target for the structural balance of the accounts of all public administrations ${ }^{10}$. This affects the State, local authorities and social security. Therefore, it aims at ensuring an overall balance. All public administrations must strive for a balance. In addition, the objective is not to ensure a balanced budget since a deficit is allowed. Finally, it should be noted that the rule relates to the structural balance, that is to say - the state deficit - which does not depend on the economic situation. In the current context, the expenses incurred to respond to the health crisis are cyclical. States thus retain the possibility of deviating from any objective of a balance.

Ultimately, since the French Revolution different conceptions of the balance of public finances have followed one another, but it is obvious that the public authorities have made the choice, from the 1990s, to promote a new concept, a third interpretation, of the balance of public finances $^{11}$. Faced with the health crisis and its economic and social effects one can wonder, if the balance is no longer an objective.

\section{The balance of public finances, a loss of an objective}

Germany is often cited as an example of a budgetary rigor, which results from enshrining the principle of balance in its basic law ${ }^{12}$. The Constitution of the German Democratic Republic of 7 October 1949 states in its Article 109 that the budget of the federation and those of the länders must in principle be balanced without the revenue from loans. Even more,

10 A. Potteau, La contribution des lois de programmation des finances publiques au respect de la discipline budgétaire européenne, "Gestion \& Finances Publiques” 2019, vol. 1, No 1, pp. 16-22.

11 Balance is often referred to as a "myth". See S. Kott, Le mythe de l'équilibre et les finances publiques, "Gestion \& Finances Publiques”, 2021 vol. 1, No 1, pp. 58-65.

12 C. Soulay, $L a$ «règle d'or» des finances publiques en France et en Allemagne : convergence au-delà des différences?, "Revue Française de Finances Publiques” 2010, No 112, pp. 187-203. 
in 2009, a constitutional revision introduced a kind of a debt brake ${ }^{13}$. Article 115 of the constitution now states that "income and expenditure must be balanced without income from loans. This principle is satisfied if the receipts from borrowing do not exceed 0.35 percent of the gross national product”. However, since the spring of 2020 and until today, with the 2021 budget, this debt brake has been suspended to allow the financing of the economic and financial decisions necessary to face the health crisis. The issue of a balanced public finances is, therefore, less topical, even in states which have legally and constitutionally bound themselves to respect a balanced budget objective.

In Germany as elsewhere, other ways are emerging. Another objective is emerging which results in relativizing the importance attached to a rule that the "gendarme state" or the "welfare state" hardly respects, whether it is a question of budgetary or financial balance ${ }^{14}$.

This is what the Nobel laureate Esther Duflo, for whom, last spring, we were given a "great Keynesian moment" 15 , suggests in particular. For this economist, the state is not a private person or a public person like any other person. It has no obligation to balance its budget and its main purpose is to instill a confidence in the financial markets in order to borrow at the best rate. Given the current health and economic situation, it is essential for the state to continue to borrow in order to protect its population and jobs in the country. Finally, according to her, the question that will arise at the end of the crisis is undoubtedly not that of the balance of the budget (France closed the year 2020 with more than 2,600 billion euros of public debt and a deficit exceeding $7 \%$ of GDP), but rather the question of whether this is not the time to initiate the structural reforms that French legal and economic system has needed for several decades. In such a framework of thought, the public debt, the deficit and the budget imbal-

13 D. Capitant, Le frein à la dette en Allemagne, "Revue Française de Finances Publiques" 2012, No 117, pp. 149-159.et s.; A. Levade, Les normes de l'Union européenne et l'équilibre budgétaire des États, "Revue Française de Finances Publiques" 2012, No 117, pp. 69-84.

14 J.-L. Albert, L'urgence sanitaire et certains inaperçus budgétaires et comptables publics, "Revue Française de Finances Publiques” 2020, No 152, pp. 123-132.

1531 March 2020, interview in France Inter radio. 
ance are no longer perceived as "good" or "bad". They are a one-off instrument, a powerful lever for reforming the state. In such a configuration, the answers to the climate issue seem to be able to be found in the recourse to debt, which financially covers the tools to encourage and sanction behavior harmful to the environment and the positive actions of the State to reduce greenhouse gas emissions.

Such a conception of the balance of public finances is not without making one think of that of the school of endogenous growth, which appeared in the United States at the beginning of the 1990s. This school notably developed the idea that certain public expenses are not open to criticism but, on the contrary, are likely to stimulate economic development. These interventions make today's spending and debt to generate revenue or savings in the future.

Likewise, it is essential to continue the pension reform initiated at the start of 2020 and suspended due to the health crisis.

In 1945, when social security was created, the legislature established a principle of distribution aimed at solidarity between generations. Each year, workers and their employers pay contributions, the proceeds of which are distributed among retirees to finance their pensions. In return for this intergenerational solidarity, the contributors themselves acquire retirement pension rights for future generations. However, this system shows its limits due to the aging of the population. Indeed, pensions paid to current retirees are financed by debt, which their grandchildren will repay. In addition, an increasingly small fraction of the population (the working population) is financially supporting the needs of an increasingly large fraction (the retirees). It would, therefore, be urgent to reform our pension system, which the Delevoye report recommended in $2019^{16}$. The bill tabled in January 2020 proposed to put an end to special schemes, the retirement age was to be increased from 62 to 64 years and each remuneration was to be the subject of contributions making it possible to acquire points for the retirement calculation. It seems important to continue reforming the pension system to strengthen its justice (standardize the

16 J.-P. Delevoye, Pour un système universel de retraite, rapport au Président de la République, juillet 2019, $130 \mathrm{p}$. 
system) and ensure the sustainability of its funding (increase the duration of contributions). It would be a shame to use bad economic figures as a pretext for not pursuing this reform, even if it results in increasing public debt since it is a reform of the future that will make our retirement system sustainable.

As we can see, the balance (budgetary or financial) of public finances is an old objective, the meaning, value and legal scope of which have constantly varied ${ }^{17}$. With the "organic law" of 1 August 2001, the State made the choice to make a balance be a central principle that should be called for while allowing society to be shaped according to needs, without being bound by extreme budgetary rigor $^{18}$. Balancing public finances is now seen as just one tool among others for transforming our society ${ }^{19}$. Getting into debt is ultimately neither enviable nor reprehensible. It is above all a matter of ensuring the sustainability of the public financial system and perhaps the structure of our national community.

\section{Bibliography:}

Albert J.-L., L'urgence sanitaire et certains inaperçus budgétaires et comptables publics, “Revue Française de Finances Publiques” 2020, No 152, pp. 123-132.

Albert J.-L., Finances publiques, 11 ${ }^{\mathrm{ème}}$ éd., Dalloz, 2019.

Allix E., Traité élémentaire de science des finances et de législation financière française, Paris, Rousseau \& cie, 6éd., 1931.

Audiffret (d') Ch., Le système financier de la France, volume 2, 1863.

Ballandras-Rozet C., Les principes budgétaires à l'épreuve de la crise sanitaire, “Revue Française de Finances Publiques” 2020, No 152, pp. 101-122.

Capitant D., Le frein à la dette en Allemagne, "Revue Française de Finances Publiques” 2012, No 117, pp. 149-159.

Chaigneau M.-A., Le dogme de l'équilibre financier: plaidoyer pour des finances publiques saines et une fiscalité juste, SPM, 2019.

17 C. Ballandras-Rozet, Les principes budgétaires à l'épreuve de la crise sanitaire, "Revue Française de Finances Publiques” 2020, No 152, pp. 101-122.

18 M. Lascombe, Les vicissitudes de la règle d'or budgétaire [in:] Mélanges en l'honneur du Professeur Joël Molinier, Paris 2012, p. 374.

19 C. Viessant, L'équilibre budgétaire, un principe constitutionnel impossible?, "Revue Française de Finances Publiques” 2020, No 150, p. 83. 


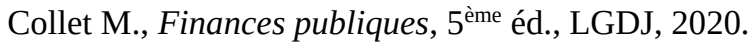

Fourastié J., Les Trente Glorieuses, ou la révolution invisible, Fayard, 1979.

Kott S., Le mythe de l'équilibre et les finances publiques, "Gestion \& Finances Publiques” 2021, vol. 1, No 1, pp. 58-65.

Lascombe M., Les vicissitudes de la règle d'or budgétaire [in:] Mélanges en l'honneur du Professeur Joël Molinier, Paris, LGDJ, 2012.

Levade A., Les normes de l'Union européenne et l'équilibre budgétaire des États, “Revue Française de Finances Publiques” 2012, No 117, pp. 69-84.

Pariente A., Équilibre des finances publiques et programmation pluriannuelle, “Revue Française de Finances Publiques” 2012, No 117, pp. 87-98.

Potteau A., La contribution des lois de programmation des finances publiques au respect de la discipline budgétaire européenne, "Gestion \& Finances Publiques” 2019, vol. 1, No 1, pp. 16-22.

Soulay C., La "règle d'or » des finances publiques en France et en Allemagne: convergence au-delà des différences?, "Revue Française de Finances Publiques” 2010, No 112, pp. 187-203.

Tallineau L., Chapitre introductive [in:] L'équilibre budgétaire, Économica, 1994.

Viessant C., L'équilibre budgétaire, un principe constitutionnel impossible?, “Revue Française de Finances Publiques” 2020, No 150, pp. 83-97. 